\title{
FIRM HETEROGENEITY AND THE LABOUR MARKET EFFECTS OF TRADE LIBERALISATION
}

\author{
HARTMUT EGGER \\ UDO KREICKEMEIER
}

\section{CESIFO WORKING PAPER NO. 2000 \\ CATEGORY 4: LABOUR MARKETS \\ MAY 2007}

Presented at CESifo Area Conference on Global Economy, April 2007

An electronic version of the paper may be downloaded

- from the SSRN website:

- from the RePEc website:

www.SSRN.com

- from the CESifo website:

www.RePEc.org

www.CESifo-group.de 


\title{
FIRM HETEROGENEITY AND THE LABOUR MARKET EFFECTS OF TRADE LIBERALISATION
}

\begin{abstract}
This paper develops a model that incorporates workers' fair wage preferences into a general equilibrium framework with monopolistic competition between heterogeneous firms à la Melitz (2003). By assuming that the wage considered to be fair by workers depends on the productivity and thus the economic success of the firm they are working in, we can study the determinants of profits, involuntary unemployment and within-group wage inequality in a unified framework. We use this model to investigate the effects of globalisation. In a benchmark case with identical costs of entering domestic and foreign markets, there are gains from trade accompanied by distributional conflicts, which have so far not been accounted for in the literature: a simultaneous increase of average profits and involuntary unemployment as well as a surge in within-group wage inequality.
\end{abstract}

JEL Code: F12, F15, F16.

Keywords: heterogeneous firms, fair wages, unemployment, wage inequality, trade liberalisation.

Hartmut Egger
Socioeconomic Institute
University of Zurich
Zürichbergstr.14
8032 Zurich
Switzerland
egger@wwi.unizh.ch

Hartmut Egger

Socioeconomic Institute

University of Zurich

ürichbergstr. 14

Switzerland

egger@wwi.unizh.ch

May 10, 2007

We thank Andrew Bernard, Josef Falkinger, Rod Falvey, Marc Melitz, Doug Nelson and James Tybout as well as participants at the CAG Workshop on Locations, Regions and Global Competition, the CESifo Area Conference on Global Economy, the European Research Workshop on International Trade (ERWIT) in Vienna, the ETSG Annual Conference in Vienna, the GEP Workshop on Frontiers in International Trade, the Göttingen Workshop in International Economics, the Midwest International Economics Meeting at Purdue University in West Lafayette, the Royal Economic Society Meeting at the University of Warwick, the ZeuthenWorkshop on International Trade and Investment at the University of Copenhagen and seminar participants at the University of Cyprus, the University of Konstanz, the University of Kiel and the University of Tübingen for helpful comments. Kreickemeier gratefully acknowledges financial support from The Leverhulme Trust under Programme Grant F114/BF. 


\section{Introduction}

It is by now well established that firms in all sectors are heterogeneous with respect to key variables including productivity, size, and export status. ${ }^{1}$ Given these empirical regularities, it seems natural to expect that workers would rather work for a successful (i.e. high-productivity) firm than for a competitor in the same industry with low productivity. However, in the established models that account for firm heterogeneity workers are indifferent between employers because the labour market is assumed to be perfectly competitive, and hence workers of a given type are paid the same wage in all firms. ${ }^{2}$ In this paper, we develop a framework in which firm performance matters for workers, as more successful firms pay higher wages. This is possible because the labour market is imperfectly competitive. By accounting for the interaction between firm heterogeneity and labour market imperfections, our model allows us to shed new light on an issue that is a prime concern to policy makers and the general public alike: the impact of international competition on domestic labour markets. ${ }^{3}$

One tractable framework that allows for firm heterogeneity in general equilibrium is given by Melitz (2003). In the Melitz model, active firms in the market are heterogeneous with respect to their productivity levels. They supply their output under monopolistic competition and active firms make positive profits in equilibrium. We introduce labour market imperfections into this framework by means of a fair wage-effort mechanism similar to the one put forward in Akerlof and Yellen (1990). ${ }^{4}$ The original Akerlof and Yellen

\footnotetext{
${ }^{1}$ The empirical literature has provided evidence for a selection of the best firms into export status (Clerides, Lach and Tybout, 1998; Bernard and Jensen, 1999).

${ }^{2}$ Influential contributions to the theoretical literature on heterogeneous firms in open economies are Bernard, Eaton, Jensen and Kortum (2003) and Melitz (2003).

${ }^{3}$ See Scheve and Slaughter (2001) for a review of poll data from the U.S. on questions related to globalisation. They show that critical views held by the general public on this topic are due to the expectation of negative labour market effects.

${ }^{4}$ Efficiency wages are a standard way to introduce labour market imperfections into models of international trade. While early contributions have put emphasis on the shirking motive of workers in order to explain wage rigidity (see Matusz, 1994, 1996), more recent theoretical work has focused on Akerlof's (1982) fairness approach (see Kreickemeier and Nelson, 2006; Egger and Kreickemeier, 2007; Grossman
} 
framework is modified by introducing a rent-sharing motive as a determinant of workers' fair wage preferences. Specifically, we assume that the wage considered to be fair depends inter alia on the productivity level (and thus the economic success) of the employer. The firm-specific component in the fair wage implies that ex ante identical workers earn different wages in equilibrium, with the factor income increasing in the productivity level of the firm in which a worker is employed. ${ }^{5}$

This framework allows us to analyse how the rent-sharing motive of workers influences the productivity distribution of active firms, aggregate output, and average profits in equilibrium. There are interesting feedback effects on the labour market as well, as the fair wage-effort mechanism induces not only wage inequality among workers employed in different firms, but also involuntary unemployment. Having derived the closed economy equilibrium of our model, we show how fairness preferences and firm heterogeneity interact in determining the consequences of trade liberalisation.

Our main results are as follows: In the closed economy equilibrium, we find that the more important the rent sharing motive is in workers' fair wage preferences, the lower becomes average productivity, with adverse consequences for total output, average profits and aggregate employment. Trade liberalisation in the presence of fixed costs of exporting leads, as in the Melitz model, to a selection of the best firms into export status and exit of the least productive producers, thereby influencing all aggregate variables in the model. In a benchmark version of the model where fixed costs are the same across all markets, the self-selection process leads to gains from trade and raises average profits of active firms. At the same time, both wage inequality and the unemployment rate increase, thereby indicating distributional conflicts induced by trade liberalisation. A further notable feaand Helpman, 2007). There is considerable empirical support for a mechanism of this type, as illustrated in the review articles by Howitt (2002) and Bewley (2005). Both stress the wide extent and strength of evidence supporting the fair wage model from a range of sources including: surveys of managers and workers, firm-level studies of pay and termination patterns, and experiments.

${ }^{5}$ Fehr and Gächter (2000, p. 172) point out that the idea of gift exchange, which underlies the fair wageeffort hypothesis, implies that "more profitable firms pay higher wages". This supports a firm internal reference perspective, with the wage considered to be fair by workers depending on the economic success of the firm they are working in. 
ture of our model is the coexistence of involuntary unemployment and positive profits in equilibrium. This allows us to address an issue that has been of some concern recently (and perhaps not so recently as well) to many politicians as well as the popular press: the simultaneous occurrence of increasing profits and increasing unemployment in the face of globalisation. ${ }^{6}$ Our results indicate that the selection process among firms induced by trade liberalisation is a candidate for explaining such developments.

While existing contributions to the literature on heterogeneous firms and trade typically abstract from involuntary unemployment, some look - as we do - at the effect of trade liberalisation on wage inequality. The focus in these papers is on the differential effect that globalisation has on workers that belong to different skill groups. ${ }^{7}$ The model in the present paper complements the analysis of inter-group relative wage effects by focussing on the impact that trade has on the wage distribution of ex ante identical workers. There is well documented evidence across many countries that within-group wage inequality is important and has increased (see Katz and Autor, 1999; Barth and Lucifora, 2006). Although the observed increase in within-group wage inequality has been parallel to the recent surge in intermediate goods trade (usually referred to by the term international outsourcing), theoretical explanations have so far predominately focussed on two other sources: technological progress and/or organisational change (see Galor and Moav, 2000; Aghion, Howitt and Violante, 2002; and Egger and Grossmann, 2005). In this literature the role of empirically unobservable individual characteristics (like learning abilities, or analytical and social skills) has been in the centre of interest. By modelling the interaction of firm heterogeneity and rent-sharing motives, our analysis identifies a new factor which may explain the intertemporal pattern of within-group wage inequality: changes in the

\footnotetext{
${ }^{6}$ As a case in point, the International Herald Tribune remarks on 11 April 2005 that across wealthy nations "job creation stalled at a time when corporate profits are soaring."

${ }^{7}$ Bernard, Redding and Schott (2007) address the impact of trade liberalisation on wage inequality in a two-country, two-sector, two-factor model with a continuum of heterogeneous firms. Yeaple (2005) and Davidson, Matusz and Shevchenko (2006) study the impact of globalisation on the wage distribution in models where producers, depending on their production technology, hire workers of different skill levels. All three models shed new light on the effect of globalisation on the skill premium.
} 
composition and relative size of firms due to trade liberalisation. ${ }^{8}$

The structure of the paper is as follows. In section 2, we introduce a closed economy version of our model. Section 3 looks at the effect of globalisation in a benchmark version of the model where fixed costs are the same across all markets. Section 4 addresses the robustness of our results. First we allow fixed costs to differ between markets, and second we look at the role of market size effects due to external economies of scale that are excluded in the main part of the paper. Section 5 concludes.

\section{Fair Wages and Firm Heterogeneity in a Closed Economy}

Consider an economy which is endowed with $L$ units of labour. Two types of goods are produced: differentiated intermediate goods and homogeneous final output.

\subsection{The Model: Basics}

Final output is a normalised CES-aggregate of all available intermediate goods. Following Blanchard and Giavazzi (2003), we assume

$$
Y=\left[M^{-(1-\rho)} \int_{v \in V} q(v)^{\rho} d v\right]^{1 / \rho}, \quad 0<\rho<1,
$$

with the measure of set $V$ representing the mass of available intermediate goods $M$. In the (hypothetical) case where the final goods sector used an equal quantity $q$ of all intermediate inputs, the production technology in (1) would yield $Y=M q$, and hence increasing $M$ for a given aggregate level of input would not increase aggregate output. As trade liberalisation in our model increases the mass of available input varieties, specification (1) eliminates one potential mechanism through which freer trade could influence aggregate output, namely external scale effects. This mechanism is well understood, of course, from Ethier (1982). Closing down this channel of influence allows us to focus on the effect that

\footnotetext{
${ }^{8}$ Waelde and Weiss (2007) analyse the impact of economic integration on within-goup wage inequality in a setting with homogeneous firms. They account for differences of workers with respect to unobservable individual characteristics and therefore can explain effects of trade liberalisation on wage inequality within rather than across firms. In this respect, the findings of our analysis are complementary to theirs.
} 
is new and specific to the heterogeneous firm literature à la Melitz (2003): the impact of trade liberalisation on the productivity distribution of active firms. ${ }^{9}$

We take final output as the numéraire and assume perfect competition in the final goods market. The price index corresponding to the CES-aggregated good $Y$ is given by

$$
P=\left[M^{-1} \int_{v \in V} p(v)^{1-\sigma} d v\right]^{\frac{1}{1-\sigma}},
$$

with $\sigma \equiv 1 /(1-\rho)$ being the elasticity of substitution between the different varieties of intermediate goods. Due to the choice of numéraire, we have $P=1$. Using this normalisation, profit maximisation of competitive final goods producers leads to the following demand for variety $v$ :

$$
q(v)=\frac{Y}{M} p(v)^{-\sigma}
$$

At the intermediate goods level, we assume a continuum of firms, each producing a unique variety. Output $q$ is linear in labour input $l$ and depends on productivity level $\phi: q=\phi l$. Labour input is measured in efficiency units, depending on the number of workers and their effort level. There is a fixed input requirement $f$ for each intermediate good, which is assumed to consist of invested final output $Y$ and will be referred to as beachhead cost in the following. ${ }^{10}$ Firms share the same $f>0$ but differ in their productivity levels $\phi .{ }^{11}$ Intermediate goods producers are monopolistically competitive. Facing (3), they choose the profit-maximising price

$$
p(\phi)=\frac{w(\phi)}{\rho \phi \varepsilon},
$$

with $w(\phi)$ denoting the wage paid to a physical unit of labour (a worker) in a firm with productivity $\phi$ and $\varepsilon$ being the effort level provided by workers. Hence, $w(\phi) /(\phi \varepsilon)$ is the

\footnotetext{
${ }^{9}$ We consider a more general production technology that encompasses both the Blanchard-Giavazzi and Ethier specifications as special cases in subsection 4.2.

${ }^{10}$ Beachhead costs are associated with investment that is a prerequisite for serving consumers in a particular economy (like investment in the local distribution system).

${ }^{11}$ Expressing fixed cost in terms of final output rather than labour (as in Melitz (2003)) is the natural way to retain the assumption of fixed costs that are the same across firms in a framework that features firm-specific wage rates.
} 
marginal cost of a firm with productivity level $\phi$, and the price is a constant markup $1 / \rho$ over marginal cost.

Following Akerlof and Yellen (1990), we assume that workers have a preference for fairness and condition their effort $\varepsilon$ on the wage they are paid relative to the wage they consider to be fair, $\hat{w}$. If firms pay at least the fair wage, workers provide the normal level of effort, which, for notational simplicity, is set equal to one. Effort decreases proportionally if the wage falls short of the fair wage. Formally, we have $\varepsilon=\min (w / \hat{w}, 1)$, as in Akerlof and Yellen (1990). Profit maximising firms have no incentive to pay less than the fair wage, and hence we can safely assume that they pay $\hat{w}$. This implies $\varepsilon=1$, and hence the distinction between workers and efficiency units of labour becomes obsolete in the following.

In line with most of the existing literature on the fairness approach to efficiency wages, we assume that the fair wage is a weighted average of two factors: the first one being firm-internal and the second one being related to market forces. Similar to Kreickemeier and Nelson (2006), we associate the second component with the average wage income per worker, i.e. the average wage of employed workers $(\bar{w})$ times the employment rate $(1-U)$. The firm-internal component of the reference wage depends on the economic success (or the "market potential") of the employer and is given by the productivity of the firm an individual is working in, $\phi{ }^{12}$ In line with Akerlof (1982) and Danthine and Kurmann (2006), we assume that the reference wage is a geometric average of the above components:

$$
\hat{w}(\phi)=\phi^{\theta}[(1-U) \bar{w}]^{1-\theta},
$$

where $\theta \in[0,1]$ can be interpreted as a fairness (or rent-sharing) parameter. Taking into account $\hat{w}(\phi)=w(\phi)$, the fair wage specification in (5) gives rise to identical wages in all

\footnotetext{
${ }^{12}$ Agell and Lundborg (1992, p. 302) note that a worker's reference set may include the return to the firm owner and that in this case the fair wage model provides a simple "explanation for the empirical fact that workers typically obtain wages that are correlated with firm-specific profit rates." In a more recent paper, Danthine and Kurmann (2006) make the reference wage dependent on output per worker, which equals $\phi$ in our analysis. Crucially, however, these two contributions do not account for productivity differences across firms and product market imperfections.
} 
firms if $\theta=0$ (cf. Melitz, 2003), while wages are firm-specific if $\theta>0$. In the limiting case of $\theta=1$, all intermediate goods producers have identical marginal production costs $w(\phi) / \phi=1$.

The result that more productive firms pay higher wages is not specific to our fair wage formulation in (5). As long as the firm-specific component of the reference wage is an increasing function of the productivity level, our model leads to wage differentiation. However, the simplifying assumption that the firm-specific component equals the productivity level is particularly attractive because it allows us discuss the two outcomes no wage differentiation and identical marginal production costs as limiting cases of our analysis. ${ }^{13}$ It should be noted that in line with previous fair-wage models, we implicitly assume that hiring is a two stage process, with firms deciding upon wage payments and employment levels at stage one, and workers deciding upon their effort provision at stage two. As it is not feasible by assumption to write a contract on the effort provision of workers (because the individual effort level is not observable), it is not attractive for firms to accept an outsider's offer at stage one to work for a lower wage, as this worker will adjust his fair wage expectation after being hired by the respective employer. ${ }^{14}$

\subsection{Firm Distribution and Average Productivity}

Combining (3) and (4), revenues and profits of intermediate goods producers are given by

$$
r(\phi)=\frac{Y}{M}\left(\frac{w(\phi)}{\rho \phi}\right)^{1-\sigma}, \quad \pi(\phi)=\frac{Y}{\sigma M}\left(\frac{w(\phi)}{\rho \phi}\right)^{1-\sigma}-f,
$$

where $\varepsilon=1$ has been used. Accounting for (5), we see that the ratios of any two firms' wages and prices depend on the ratio of their productivity levels and the fairness parameter

\footnotetext{
${ }^{13}$ Although the specific formulation of the reference wage is not essential for wage differentiation across firms in our model, the efficiency wage framework seems to be crucial. For example, Felbermayr and Prat (2007) find that all firms pay the same wage if unemployment in a Melitz-type model of a closed economy arises due to search frictions.

${ }^{14}$ Fehr and Falk (1999) have designed a two stage loboratory experiment to show that the impossiblity to fix the effort level of workers through a contract is essential for avoiding successful underbidding of wages by those who are non-employed. Bewley (2005) documents evidence for the reluctance of managers to hire outside workers at lower wages and associates this finding with the fair wage-effort hypothesis.
} 
$\theta$ :

$$
\frac{w\left(\phi_{1}\right)}{w\left(\phi_{2}\right)}=\left(\frac{\phi_{1}}{\phi_{2}}\right)^{\theta}, \quad \frac{p\left(\phi_{1}\right)}{p\left(\phi_{2}\right)}=\left(\frac{\phi_{1}}{\phi_{2}}\right)^{\theta-1} .
$$

Accordingly, we find

$$
\frac{q\left(\phi_{1}\right)}{q\left(\phi_{2}\right)}=\left(\frac{\phi_{1}}{\phi_{2}}\right)^{\sigma(1-\theta)}, \quad \frac{r\left(\phi_{1}\right)}{r\left(\phi_{2}\right)}=\left(\frac{\phi_{1}}{\phi_{2}}\right)^{\xi}
$$

and

$$
\frac{l\left(\phi_{1}\right)}{l\left(\phi_{2}\right)}=\left(\frac{\phi_{1}}{\phi_{2}}\right)^{\xi-\theta}
$$

with $\xi \equiv(\sigma-1)(1-\theta)$. A more productive firm has a higher output level, pays higher wages, demands lower prices, and realises higher revenues and profits than a less productive firm. The higher is $\theta$, the higher is ceteris paribus the wage differential and the lower is the output and revenue differential between firms of differing productivities.

The employment level in more productive firms is higher if and only if $\xi>\theta$ and therefore $\sigma(1-\theta)-1>0$. On the one hand, for any given level of output more productive firms need fewer workers. On the other hand, due to lower marginal costs they charge lower prices and have higher output. For high levels of $\sigma$, price differences between varieties translate into large output differences, and therefore firm-level employment increases with firm productivity. In contrast, a higher $\theta$ increases relative marginal costs of more productive firms, thereby mitigating output differences between producers. Employment may therefore be lower in more productive firms.

The positive correlation between productivity levels, profits and wage payments, arising under fair wage specification (5), is well in line with the empirical findings on rent sharing in firms. Blanchflower, Oswald and Sanfey (1996) for example document that a rise in a sector's profitability leads to higher wage payments in that sector. And Hildreth and Oswald (1997) show that changes in profitability induce changes of wages in the same direction. Furthermore, there is empirical evidence for higher wage payments in, with respect to their employment levels, larger firms. Using information from the New Worker Establishment Characteristics Database, Bayard and Troske (1999) conclude that in the U.S. "a significant portion of the firm-size wage premium is the result of employees working 
in more productive establishments" (p. 102). Winter-Ebmer and Zweimüller (1999) find that "firm-size wage differentials in Switzerland cannot be explained by job-heterogeneity" and that only "half of the differential (the size of which is comparable to the differential in the United States) is accounted for by worker heterogeneity" (p. 93). These empirical findings on firm (or better employment) size related wage payments are consistent with the formal relationships in (7) and (9), if a sufficiently small $\theta>0$ leads to $\sigma(1-\theta)-1>0$.

In a next step, we determine a weighted average of productivity levels $\tilde{\phi}$ which is defined in a way to ensure that the quantity $q(\tilde{\phi})$ is equal to the average output per firm, $Y / M$. From (3), this implies $p(\tilde{\phi})=1$. Now, rewrite $(2)$ as

$$
P=\left[\int_{0}^{\infty} p(\phi)^{1-\sigma} \mu(\phi) d \phi\right]^{\frac{1}{1-\sigma}},
$$

where $\mu(\phi)$ is the distribution of productivity parameters of active firms over a subset of $(0, \infty)$. From $(7)$, we have $p(\phi)=p(\tilde{\phi})(\phi / \tilde{\phi})^{\theta-1}$. Substituting into $\left(2^{\prime}\right)$ and using $P=p(\tilde{\phi})=1$ implies

$$
\tilde{\phi} \equiv\left[\int_{0}^{\infty} \phi^{\xi} \mu(\phi) d \phi\right]^{1 / \xi} .
$$

The average productivity $\tilde{\phi}$ gives the weighted harmonic mean of the $\phi$ s, with relative output levels $q(\phi) / q(\tilde{\phi})$ serving as weights. Denoting by $R$ aggregate revenues in this economy and by $\Pi$ aggregate profits we find - analogous to Melitz (2003) - that $R=$ $\operatorname{Mr}(\tilde{\phi})$ and $\Pi=M \pi(\tilde{\phi})$. Together with the previous results $P=p(\tilde{\phi})$ and (by definition) $Y=M q(\tilde{\phi})$, this illustrates the usefulness of the particular average defined in (10): The aggregate product market variables in our model are identical to what they would be if the economy hosted $M$ identical firms with productivity $\tilde{\phi}$.

\subsection{Market Entry and Average Profit}

With respect to entry and exit of intermediate goods producers, we follow Melitz (2003) and assume an unbounded pool of prospective entrants into the intermediate goods market. Prior to entry, firms are identical. To enter, firms must make an initial investment in the form of $f_{e} \geq 0$ units of final output. These fixed costs are hereafter sunk. After the 
initial investment, firms draw their productivity from a cumulative distribution $G(\phi)$ with density $g(\phi)$. As in Helpman, Melitz and Yeaple (2004) and Baldwin (2005), the Pareto distribution is used to parametrise $G(\phi)$ :

$$
G(\phi)=1-\phi^{-k} \quad g(\phi)=k \phi^{-(k+1)},
$$

where the lower bound of productivities is normalised to 1 without loss of generality (i.e. $\phi \geq 1$ ), and $k$ is a strictly positive parameter. ${ }^{15} \mathrm{~A}$ firm drawing productivity $\phi$ will produce if and only if the expected stream of profits is non-negative. For the sake of clarity, we should emphasise at this stage the importance of distinguishing the two types of fixed costs present in the model: initial investment costs $f_{e}$, which must be incurred to participate in the productivity draw and may, therefore, be associated with costs of developing a blueprint; and per-period beachhead costs $f$, which are associated with entry into the domestic market and investment in the local distribution system.

If a firm starts production, it faces a probability of death $\delta>0$ (exogenous and independent of $\phi$ ) in each period. We account for an infinite number of time periods and focus on steady state equilibria in which the aggregate variables remain constant over time. Assuming that there is no discounting, each firm's value function can be written as

$$
v(\phi)=\max \left\{0, \sum_{t=0}^{\infty}(1-\delta)^{t} \pi(\phi)\right\}=\max \left\{0, \frac{\pi(\phi)}{\delta}\right\} .
$$

The lowest productivity compatible with a non-negative expected profit stream of a firm that chooses to start production is denoted by $\phi^{*}$. Formally, $\phi^{*}=\inf \{\phi: v(\phi)>0\}$. From (12), this implies $v\left(\phi^{*}\right)=\pi\left(\phi^{*}\right)=0$.

The ex post distribution of productivities, $\mu(\phi)$, is conditional on a successful draw. Hence,

$$
\mu(\phi)=\left\{\begin{array}{cc}
\frac{g(\phi)}{1-G\left(\phi^{*}\right)}=\frac{k}{\phi}\left(\frac{\phi^{*}}{\phi}\right)^{k} & \text { if } \phi \geq \phi^{*} \\
0 & \text { otherwise }
\end{array},\right.
$$

\footnotetext{
${ }^{15}$ Using firm level data for eleven European countries, Del Gatto, Mion and Ottaviano (2006) show that "Pareto is a fairly good approximation" (p. 17) of the productivity distribution in their data set.
} 
where $1-G\left(\phi^{*}\right)$ is the ex ante probability of a successful draw, i.e. a draw that results in $\phi \geq \phi^{*}$. Together, (10) and (13) determine $\tilde{\phi}$ as a function of cutoff productivity level $\phi^{*}$ :

$$
\tilde{\phi}=\left(\frac{k}{k-\xi}\right)^{1 / \xi} \phi^{*}
$$

where $k>\xi$ is assumed. The differential between the average productivity of active firms $\tilde{\phi}$ and the cutoff productivity $\phi^{*}$ is therefore only a function of the model parameters $\sigma, \theta$ and $k$.

We now turn to the determination of the cutoff productivity $\phi^{*}$. The free entry condition requires that in equilibrium the sunk costs $f_{e}>0$ of entering the productivity draw are equal to the present value of the average profits of active firms, $\bar{\pi} \equiv \Pi / M$, multiplied by the probability of a successful draw, $1-G\left(\phi^{*}\right)$. Formally, using (11), (12) and $\bar{\pi}=\pi(\tilde{\phi})$, this gives us the free entry condition (FE)

$$
\bar{\pi}=\left(\phi^{*}\right)^{k} \delta f_{e} .
$$

Clearly, $\partial \bar{\pi} / \partial \phi^{*}$ is strictly positive: With a higher cutoff productivity $\phi^{*}-$ and therefore a lower probability of getting a favourable draw - a higher average profit is needed to keep a firm indifferent between entering and staying out of the productivity draw.

A second relation between the average profit of active firms and the cutoff productivity can be derived from the condition that the marginal firm in the market makes zero profits, i.e. $\pi\left(\phi^{*}\right)=0$. As shown in (6) this implies $r\left(\phi^{*}\right)=\sigma f$, and using (8) and (14) we get the zero cutoff profit condition (ZCP), which in the case of Pareto distributed productivities is independent of $\phi^{*}$ :

$$
\bar{\pi}=\pi(\tilde{\phi})=\frac{\xi f}{k-\xi} .
$$

Figure 1 plots equations (15) and (16). The cutoff productivity level $\phi^{*}$ is determined by the intersection of the two curves and formally given by

$$
\phi^{*}=\left[\frac{\xi f}{(k-\xi) \delta f_{e}}\right]^{1 / k} .
$$

In order to ensure the existence of an equilibrium, we clearly need $\phi^{*}>1$, which is the case if $f$ is sufficiently high and/or $\delta, f_{e}$ are sufficiently small. 


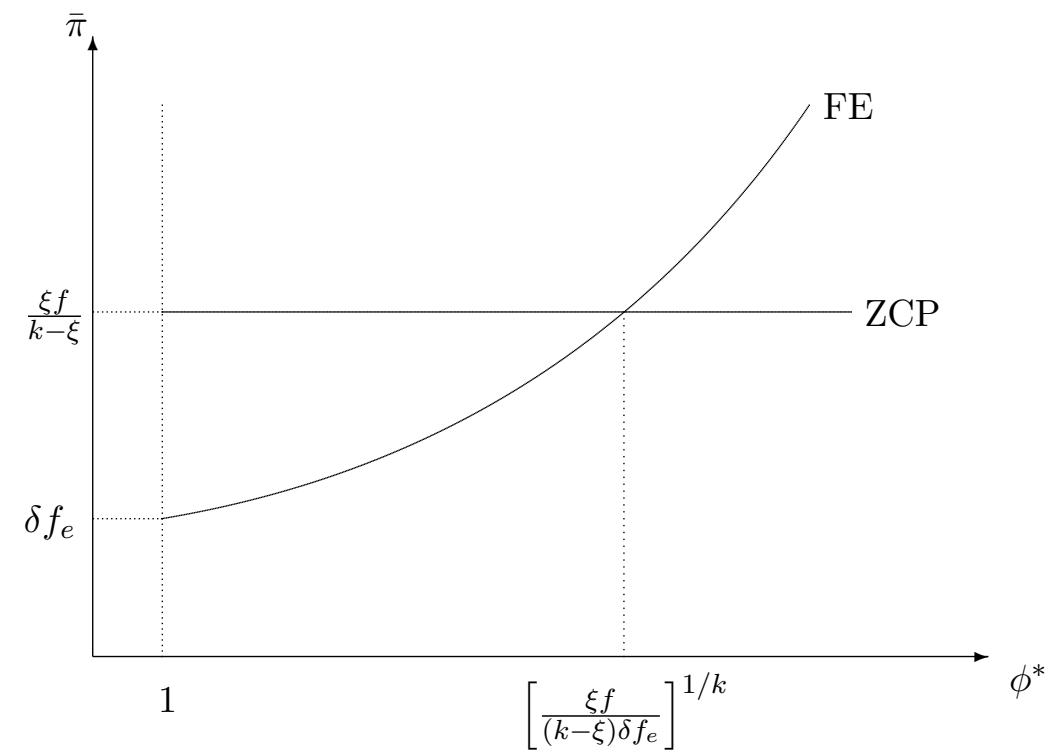

Figure 1: Determination of the cutoff productivity level

\subsection{Welfare, Unemployment and Wage Inequality}

We now look at the implication of firm heterogeneity for the aggregate variables welfare, unemployment and wage inequality.

In our model with a single homogeneous final good, per capita wage income is the natural utilitarian welfare measure. ${ }^{16}$ Given the mark-up pricing rule, per capita wage income is a constant share $\rho$ of per capita output $Y / L$, and we can therefore use both variables interchangeably to measure welfare. For notational simplicity, we use per capita output $Y / L$ in the following. We have $(1-U) \bar{w} L=\rho Y$, which can be used to substitute for $(1-U) \bar{w}$ in $(5)$. Accounting for $w(\phi)=\hat{w}(\phi)$, this gives us

$$
w(\phi)=\phi^{\theta}\left[\frac{\rho Y}{L}\right]^{1-\theta} .
$$

To determine equilibrium welfare we depict the condition for profit maximisation (4) and the modified fair wage constraint $\left(5^{\prime}\right)$, both for the average firm with $\phi=\tilde{\phi}$, in figure 2 .

\footnotetext{
${ }^{16} \mathrm{By}$ virtue of the free entry condition, the present value of aggregate profits equals total initial investment of firms that participate in the productivity draw. Hence, similar to Melitz (2003) only wage income is disposable for consumption.
} 
The two curves are labelled PMC and FWC, respectively, and their point of intersection gives

$$
Y / L=\tilde{\phi} \rho^{\theta /(1-\theta)}
$$

Due to the normalisation of final output in (1), welfare is independent of the mass of producers $M$ and the total labour endowment $L$, and therefore changes in market size per se do not exhibit a direct welfare effect.

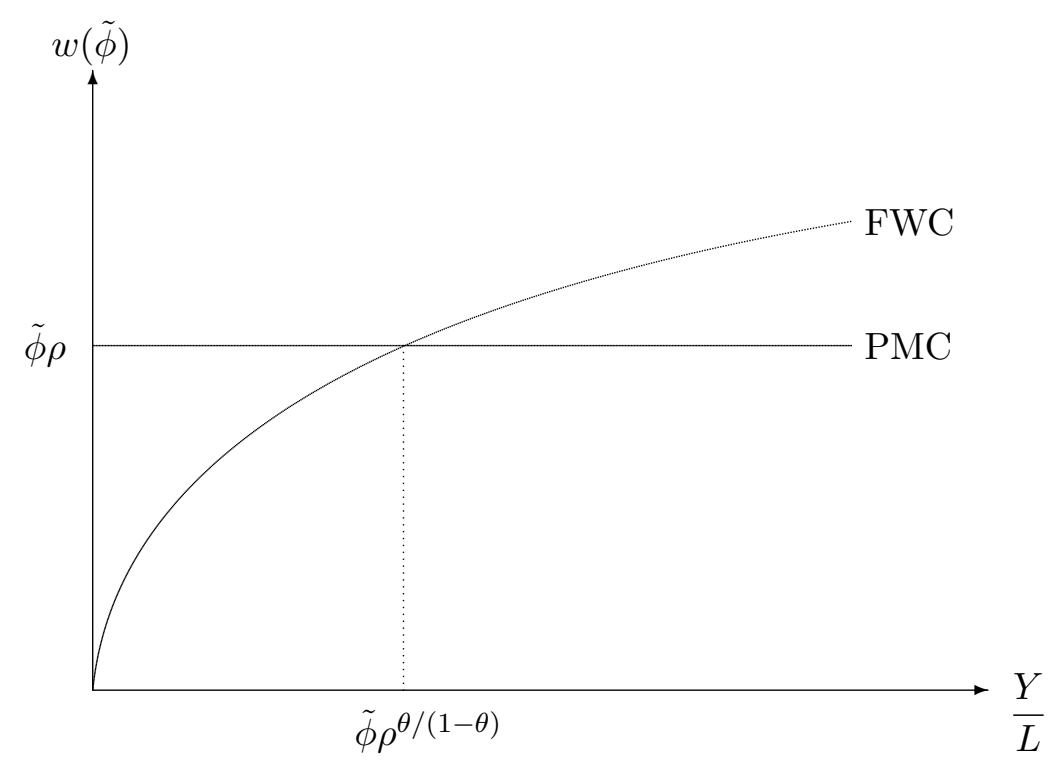

Figure 2: Determination of equilibrium welfare

The equilibrium mass of producers $M$ is determined by $\operatorname{Mr}(\tilde{\phi})=Y$. Substituting (6) and (18) gives

$$
M=\frac{Y}{r(\tilde{\phi})}=\frac{\tilde{\phi} \rho^{\theta /(1-\theta)} L}{\sigma(\pi(\tilde{\phi})+f)}
$$

Substituting $\pi(\tilde{\phi})$ from (16) we find that $M$ is proportionally increasing in both labour endowment $L$ and the average productivity level $\tilde{\phi}$.

In order to determine the rate of unemployment $U$, we make use of the accounting identity that aggregate employment $(1-U) L$ has to equal firm specific employment, 
summed over all firms $M$. By virtue of (13), we obtain

$$
(1-U) L=M \int_{\phi^{*}}^{\infty} l(\phi) \frac{k}{\phi}\left(\frac{\phi^{*}}{\phi}\right)^{k} d \phi
$$

Using (9) and (14), this can be rewritten as

$$
1-U=\frac{Y}{L \tilde{\phi}}\left(\frac{k}{k-\xi}\right)^{\theta / \xi} \frac{k-\xi}{k-\xi+\theta},
$$

and substituting for $Y / L$ from (18) we get

$$
1-U=\rho^{\theta /(1-\theta)}\left(\frac{k}{k-\xi}\right)^{\theta / \xi} \frac{k-\xi}{k-\xi+\theta} .
$$

One can immediately see that $\theta=0$ implies $U=0$, showing that having the fair wage depend on a firm internal performance measure is necessary in our model to generate unemployment. With $\theta>0$, we can ensure that $U \in(0,1)$ if $k$ is large enough, implying that there are relatively many firms in the market whose productivity is close to the cutoff level. A sufficient condition that holds for all levels of $\theta \in(0,1)$ is ${ }^{17}$

$$
k \geq \frac{\sigma-1}{1-\rho^{\sigma-1}}
$$

Notably, the unemployment rate in $(21)$ is independent of parameter $L$. This is a direct consequence of the Blanchard and Giavazzi (2003)-type production technology in (1), which rules out pure market size effects on the key economic variables. That changes in labour endowments do not have an impact per se, seems to be a plausible outcome as there is no empirical support for a size pattern in the employment rate, and unemployment is a problem for large as well as small economies.

We can use (21) as well to gain insights into the distribution of wages in the model. In the empirical literature, wage rates in different percentiles are often compared (90/10 or $50 / 10)$ to gain insights on income/wage dispersion between individuals. For the purpose of analytical tractability, we choose a (slightly) different approach and focus on the ratio

\footnotetext{
${ }^{17}$ For a given $\theta, \rho^{\sigma-1} k /(k-\xi) \leq 1$ implies $R H S \leq 1$ in $(21)$. Since $k /(k-\xi)$ declines in $\theta$, we can derive (22) as a sufficient condition for an interior solution, with $R H S \leq 1$ for any possible $\theta$. Condition (22) is also sufficient for $w\left(\phi^{*}\right) \geq(1-U) \bar{w}$, implying that employed workers earn at least the average wage income in the economy.
} 
of the average to the lowest wage rate, i.e. $\bar{w} / w\left(\phi^{*}\right)$. This inequality measure is derived in two steps. From (4) and (5) we know $(1-U)=\rho^{\theta /(1-\theta)} w(\tilde{\phi}) / \bar{w}$. Substituting into $(21)$ gives the differential between the wage paid by the average firm and the average wage as

$$
\frac{w(\tilde{\phi})}{\bar{w}}=\left(\frac{k}{k-\xi}\right)^{\theta / \xi} \frac{k-\xi}{k-\xi+\theta} .
$$

This differential is equal to one if either $\theta=0$ or $\theta=\xi$. In the former case, this is due to all firms paying the same wage. In the latter case firms pay different wages, but the two averages $w(\tilde{\phi})$ and $\bar{w}$ coincide because all firms have the same employment level, according to (9). From (7) and (14), we have $w(\tilde{\phi}) / w\left(\phi^{*}\right)=[k /(k-\xi)]^{\theta / \xi}$. Together with (23), this gives our desired inequality measure

$$
\frac{\bar{w}}{w\left(\phi^{*}\right)}=\frac{k-\xi+\theta}{k-\xi}
$$

Importantly, wage inequality is not triggered by differences in the individual characteristics of workers. But rather it is the interplay of productivity differences between firms and fairness preferences of workers which leads to wage differentiation. Since workers are identical in all respects, $\bar{w} / w\left(\phi^{*}\right)$ can be interpreted as a measure for the dispersion of wage income within a particular skill group. A focus on within-group wage inequality seems also to be justified from an empirical point of view, as within-group wage inequality is an important determinant of overall wage inequality (Juhn, Murphy, and Pierce, 1993; Katz and Autor $\left.{ }^{18}, 1999\right)$ and the increase in within-group wage inequality observed in the last three decades was - in contrast to the rise in between-group wage inequality - not confined to the U.S. (Katz and Autor, 1999; Barth and Lucifora, 2006).

\subsection{The Role of Fairness Preferences}

We have shown above that the borderline case $\theta=0$ leads to the perfectly competitive labour market outcome in our model: all firms pay the same wage and there is full employment. We now turn to more generally determining the effects that changes in $\theta$ have

\footnotetext{
${ }^{18}$ Katz and Autor (1999, Table 5) show that within-group inequality explains three-fourth of overall wage inequality in the U.S.
} 
on average profits, per capita output and the key labour market variables. These effects are summarised in the following proposition.

Proposition 1. Under parameter restriction (22), a higher $\theta$ leads to lower average profits of active firms, lower output per capita, higher unemployment and greater wage inequality.

Proof. See the appendix.

The intuition behind these results is as follows. Consider an increase in the fairness parameter. This improves the relative position of less productive firms because in relation to their more productive competitors they now pay lower wages, which mitigates the disadvantage they suffer from an unfavourable draw in the productivity lottery. Consequently, less productive firms than before can now survive in the market, and the cutoff productivity $\phi^{*}$ falls. Both the lower cutoff productivity and the steeper wage profile naturally lead to a widening in the wage differential and a decline in the average profit of active firms.

Per capita output falls due to two effects. First, holding the fairness parameter constant, the decrease in the cutoff productivity leads to a proportional decrease in average productivity and hence per capita output. Second, for a given average productivity the increase in the fairness parameter increases the fair wage demand in the average firm, and per capita output has to fall further in order to make the going wage compatible with the fair wage constraint, i.e. in order to keep workers - by reducing the average wage income in the economy - satisfied with their wage rate. It is this second-round decline in per capita output which leads to a fall in aggregate employment. The first effect, by reducing per capita income and the average productivity proportionally, leaves employment constant (see eq. (20)). There is a further effect on aggregate employment that depends on the size distribution of firms in terms of employment levels (which, as shown above, depends on $\xi-\theta)$. While the sign of this effect is ambiguous, we know from proposition 1 that it can never overturn the primary negative employment effect. 


\section{A Benchmark Model of the Open Economy}

When economists think about integration effects, they often turn to the theoretically appealing (but empirically not fully convincing) borderline case of full integration of product markets. Full integration of countries which do not differ in their economic fundamentals is formally equivalent in our model to an increase in $L$ and, under technology (1), exhibits no effect on $Y / L, U$ and $\bar{w} / w\left(\phi^{*}\right)$. Only the number of competitors $M$ rises proportionally with market size parameter $L$. However, if we account for transport costs the key macroeconomic variables no longer remain constant in the process of market integration. This is the case we are focussing on in the following.

Two types of transport costs are distinguished: (i) iceberg transport costs, which are usually considered in trade models with monopolistic competition, and (ii) fixed transport costs, which have been put forward by Melitz (2003) to explain the empirical regularity that larger, more productive firms engage in exporting. We denote by $\tau \geq 1$ the iceberg transport cost parameter and by $f_{x} \geq 0$ fixed per-period transport costs, which can be interpreted as foreign beachhead (market entry) costs and investment in the foreign distribution system. In analogy to domestic beachhead costs, $f_{x}$ is expressed in units of final output. We investigate integration between $n+1$ fully symmetric countries. This simplifies our analysis and makes country indices obsolete.

We use index $x$ to refer to variables associated with export sales, while domestic variables are left index free, as in the previous section. Export prices are given by $p_{x}(\phi)=$ $\tau p(\phi)$, with $p(\phi)$ being determined according to (4). Export sales to any partner country and the respective revenues at the firm level are given by $q_{x}(\phi)=\tau^{-\sigma} q(\phi)$ and $r_{x}(\phi)=$ $\tau^{1-\sigma} r(\phi)$, with $q(\phi)$ and $r(\phi)$ being determined according to (3) and (6), respectively. Then, under trade, total revenues of a firm with productivity level $\phi$ are given by

$$
r_{t}(\phi)=\left\{\begin{array}{cc}
r(\phi) & \text { if it does not export } \\
r(\phi)+n \tau^{1-\sigma} r(\phi) & \text { if it exports }
\end{array} .\right.
$$

Furthermore, profits associated with local sales and exports are given by,

$$
\pi(\phi)=\frac{r(\phi)}{\sigma}-f, \quad \pi_{x}(\phi)=\frac{r_{x}(\phi)}{\sigma}-f_{x},
$$


so that $\pi_{t}(\phi)=\pi(\phi)+\max \left[0, n \pi_{x}(\phi)\right]$ determines the overall (per period) profits of an active producer.

Similar to Melitz (2003), we can distinguish two scenarios. If trade costs are sufficiently low, all active firms will engage in exporting, i.e. $\phi^{*}=\phi_{x}^{*}$, while partitioning of firms by their export status arises under sufficiently high transport costs. In the latter case $\phi^{*}$ is determined by $\pi\left(\phi^{*}\right)=0$, while $\phi_{x}^{*}>\phi^{*}$ is determined by $\pi_{x}\left(\phi_{x}^{*}\right)=0$. Such a partitioning of firms requires $\pi_{x}\left(\phi^{*}\right)<0$. Substituting $r_{x}(\phi)=\tau^{1-\sigma} r(\phi)$ into (26), we can see that all firms engage in exporting if $\tau^{\sigma-1} f_{x} \leq f$, whereas $\tau^{\sigma-1} f_{x}>f$ leads to partitioning of firms by their export status. In analogy to (14), we find

$$
\tilde{\phi}_{x}=\left(\frac{k}{k-\xi}\right)^{1 / \xi} \phi_{x}^{*}
$$

and hence we have $\tilde{\phi}_{x} / \tilde{\phi}=\phi_{x}^{*} / \phi^{*}$.

The ex ante probability that a successful entrant will engage in exporting is $\chi=$ $\left[1-G\left(\phi_{x}^{*}\right)\right] /\left[1-G\left(\phi^{*}\right)\right]=\left(\phi^{*} / \phi_{x}^{*}\right)^{k}$. Since firms know their productivity levels before they decide upon their export status, $\chi$ also gives the ex post fraction of exporters. If all countries are symmetric, the total number of producers selling to one market is given by $M_{t}=M(1+n \chi)$. The weighted average productivity of all firms active in a particular country is determined in analogy to (10) and given by

$$
\begin{aligned}
\tilde{\phi}_{t} & =\left\{\frac{1}{1+n \chi}\left(\tilde{\phi}^{\xi}+n \chi \tau^{1-\sigma} \tilde{\phi}_{x}^{\xi}\right)\right\}^{1 / \xi} \\
& =\tilde{\phi}\left\{\frac{1}{1+n \chi}\left[1+n \chi \tau^{1-\sigma}\left(\tilde{\phi}_{x} / \tilde{\phi}\right)^{\xi}\right]\right\}^{1 / \xi},
\end{aligned}
$$

where $\tilde{\phi}$ is the average productivity of all domestic firms and $\tilde{\phi}_{x}$ is the average productivity of exporting firms. The difference between the two averages $\tilde{\phi}$ and $\tilde{\phi}_{t}$ is due to two effects: the lost-in-transit effect caused by goods melting away en route when variable transport costs are positive and the export-selection effect due to the fact that with partitioning it is the most productive firms who export. Inspection of (28) confirms that $\tilde{\phi}_{t}=\tilde{\phi}$ when there are no variable transport costs and all firms export. Increasing $\tau$ decreases $\tilde{\phi}_{t} / \tilde{\phi}$ directly due to the lost-in-transit effect, but increases $\tilde{\phi}_{t} / \tilde{\phi}$ due to the export-selection effect if it leads to partitioning of firms by their export status. 
The definition of $\tilde{\phi}_{t}$ in (28) ensures that the quantity produced by the average firm for its domestic market, $q\left(\tilde{\phi}_{t}\right)$, is equal to the average output per firm selling to this market, $Y / M_{t}$. In analogy to the closed economy case, we furthermore have $P=p\left(\tilde{\phi}_{t}\right)=1$, $Y=R=M_{t} r\left(\tilde{\phi}_{t}\right)$, and $\Pi=M_{t} \pi\left(\tilde{\phi}_{t}\right)$. Hence, for the open economy version of the model $\tilde{\phi}_{t}$ assumes the role that $\tilde{\phi}$ has for the closed economy version.

In the remainder of this section we look at the case where the per-period domestic beachhead costs $f$ and the per-period foreign beachhead costs $f_{x}$ are equal. This ensures partitioning of firms according to their export status - the empirically relevant case - for any strictly positive level of iceberg transport costs $(\tau>1)$. Making the model symmetric in this way allows us to bring to the forefront the role played by firm heterogeneity in the globalisation process. We delegate a discussion of the general case $f \neq f_{x}$ to section 4 . With the assumption $f_{x}=f$, and using (8) as well as $r\left(\phi^{*}\right)=\sigma f$ and $r_{x}\left(\phi_{x}^{*}\right)=\sigma f_{x}$ (from the respective zero profit cutoff conditions), we get

$$
\left(\frac{\phi_{x}^{*}}{\phi^{*}}\right)^{\xi}=\frac{r\left(\phi_{x}^{*}\right)}{r\left(\phi^{*}\right)}=\frac{\tau^{\sigma-1} r_{x}\left(\phi_{x}^{*}\right)}{r\left(\phi^{*}\right)}=\tau^{\sigma-1}
$$

Substitution in (28) gives $\tilde{\phi}_{t}=\tilde{\phi}$, where the differential of the two average productivities is independent of $\tau$ because with $f_{x}=f$ the lost-in-transit effect and the export-selection effect exactly offset each other. This simplifies the analysis dramatically because the relative size of $\phi^{*}$ and $\tilde{\phi}$ depends only on model parameters $\sigma, \theta$ and $k$, as shown in (14), and is the same in the closed and open economy. We can therefore focus on deriving the effect that opening up to trade has on the cutoff productivity $\phi^{*}$. We can furthermore see from (16) that $\pi(\tilde{\phi})$, the profit that the average firm makes in its domestic market, does only depend on model parameters $f, \sigma, \theta, k$ and therefore remains unaffected after trade liberalisation.

\subsection{Comparing Autarky and Trade}

From the definition of average productivity $\tilde{\phi}_{t}$, the average profit of active firms $\bar{\pi}_{t} \equiv \Pi / M$ in the open economy is given by $\bar{\pi}_{t}=\pi\left(\tilde{\phi}_{t}\right)\left(M_{t} / M\right)=\pi\left(\tilde{\phi}_{t}\right)(1+n \chi)$, where $\chi=\tau^{-k /(1-\theta)}$. Comparing this to the average profit in autarky, as given in (16), and using $\tilde{\phi}=\tilde{\phi}_{t}$, we 
find ${ }^{19}$

$$
\frac{\bar{\pi}_{t}}{\bar{\pi}_{a}}=1+n \chi>1
$$

Hence, average profits of active firms increase as the economy opens up to trade.

As shown above, $\phi^{*}$ is jointly determined by the free entry condition and the zero cutoff profit condition. The free entry condition is the same as in the closed economy, with $\bar{\pi}_{t}$ replacing $\bar{\pi}$ in (15). The modified zero cutoff profit condition (ZCP) becomes

$$
\bar{\pi}_{t}=\frac{\xi f}{k-\xi}(1+n \chi),
$$

using (16) as well as $\tilde{\phi}_{t}=\tilde{\phi}$. Together, (15) and (31) determine the cutoff productivity under trade. It is given by

$$
\phi^{*}=\left[\left(\frac{\xi f}{(k-\xi) \delta f_{e}}\right)(1+n \chi)\right]^{1 / k}
$$

Comparing $\phi^{*}$ to its autarky level $\phi_{a}^{*}$ as determined in (17), we see that trade liberalisation leads to a higher productivity cutoff level: $\phi^{*}>\phi_{a}^{*}$. Graphically, trade liberalisation induces an upward shift of the ZCP locus in figure 1. With the FE curve unchanged, the cutoff productivity increases.

As the ratio of average productivity $\tilde{\phi}$ and cutoff productivity $\phi^{*}$ is the same under autarky and trade, and we have $\tilde{\phi}=\tilde{\phi}_{t}$, it follows from (17) and (32) that

$$
\frac{\tilde{\phi}_{t}}{\tilde{\phi}_{a}}=(1+n \chi)^{1 / k}>1
$$

Hence, in the completely symmetric case considered here trade liberalisation induces an increase in the average productivity level of active firms: $\tilde{\phi}_{t}>\tilde{\phi}_{a}$. This translates into an increase in per capita production - and therefore welfare - for all trading economies, as shown by $(18) \cdot{ }^{20}$

\footnotetext{
${ }^{19}$ From now on, we use subscript $a$ to refer to autarky levels.

${ }^{20}$ While under production technology (1) the welfare effect is independent of the change in the mass of intermediates used in each country, it is straightforward to determine this change. In the open economy, we denote by $M_{t}$ the mass of input varieties used in final goods production, and by $M$ the mass of locally produced varieties. Noting $r\left(\tilde{\phi}_{t}\right)=r\left(\tilde{\phi}_{a}\right)$ and $Y=M_{t} r\left(\tilde{\phi}_{t}\right), M_{t} / M_{a}=\tilde{\phi}_{t} / \tilde{\phi}_{a}>1$ follows immediately from (19) and (33). Hence, in each country more varieties are used in production after trade liberalisation. The mass of local producers on the other hand declines if and only if $k>1$ : Use $(33)$ and $M_{t}=(1+n \chi) M$ to get $M / M_{a}=(1+n \chi)^{(1-k) / k}$. Note that $k>1$ is not implied by $(22)$.
} 
We now turn to the effects of trade liberalisation on unemployment. Summing up employment at the firm level we get

$$
(1-U) L=M \int_{\phi^{*}}^{\infty} l(\phi) \frac{k}{\phi}\left(\frac{\phi^{*}}{\phi}\right)^{k} d \phi+n M_{x} \int_{\phi_{x}^{*}}^{\infty} l_{x}(\phi) \frac{k}{\phi}\left(\frac{\phi_{x}^{*}}{\phi}\right)^{k} d \phi
$$

where $l(\phi)$ is the employment in a domestic firm of productivity $\phi$ for its domestic sales, while $l_{x}(\phi)=\tau^{1-\sigma} l(\phi)$ is the employment in a domestic exporting firm of productivity $\phi$ for its export production. This can be rewritten as

$$
1-U=\Gamma \frac{Y}{L \tilde{\phi}_{t}}\left(\frac{k}{k-\xi}\right)^{\theta / \xi} \frac{k-\xi}{k-\xi+\theta},
$$

with

$$
\Gamma \equiv \frac{1+n \tau^{-\frac{k+\theta}{1-\theta}}}{1+n \tau^{-\frac{k}{1-\theta}}}<1 .
$$

Substituting for $Y / L$ from (18) we get

$$
1-U=\Gamma \rho^{\theta /(1-\theta)}\left(\frac{k}{k-\xi}\right)^{\theta / \xi} \frac{k-\xi}{k-\xi+\theta},
$$

Comparing (21) with (37), we see that the move from autarky to trade increases unemployment. The results on average profits, aggregate welfare and unemployment can be summarised as follows:

Proposition 2. With positive variable transport costs and beachhead costs that are the same across all markets, opening up to international trade increases average profits of active firms, aggregate welfare and the rate of unemployment in the participating countries.

The intuition for these results is as follows. On the one hand, opening up for trade raises, all other things equal, the mass of available intermediate good varieties in each market. This fosters competition in the local market and reduces demand at the firm level (see (3)). The decline in demand renders production of marginal firms (with productivity levels close to $\phi_{a}^{*}$ ) unprofitable. On the other hand, due to relatively cheap intermediate imports from foreign high-productivity firms, aggregate output of the final good increases, thereby increasing aggregate labour income and - via the fair wage constraint $\left(5^{\prime}\right)$ - the fair 
wage for all firms. Since a higher wage reduces profits ceteris paribus (see (6)), this reduces profitability further and contributes to the exit of marginal firms. ${ }^{21}$ As a consequence, only the more productive firms survive under openness, the most productive firms export and consequently become bigger, and both average profits and average productivity increase. By virtue of equation (18), this leads to higher per capita output and therefore higher aggregate welfare.

The aggregate employment effect of trade liberalisation is driven by two effects that work in opposite directions. On the one hand, production of intermediate inputs increases, and with labour as the only input this increases aggregate employment, ceteris paribus. On the other hand, average firm productivity increases, and hence fewer workers are needed to produce a given quantity of intermediates. In the limiting case of zero variable transport $\operatorname{costs}(\tau=1)$ the output effect and the productivity effect exactly offset each other, and globalisation has no effect on aggregate employment. With positive variable transport cost, the case considered here, the productivity effect dominates, and aggregate employment falls.

With welfare and employment effects at hand, we now show how a movement from autarky to trade affects wage payments, starting with the wage of the average worker, $\bar{w}=\rho(Y / L) /(1-U)$. From proposition 2, per capita output rises while the employment rate declines, and hence $\bar{w}$ increases unambiguously. However, there are also distributional consequences through changes in the wage dispersion. The wage differential between the worker receiving the average wage and the lowest paid worker can be derived in analogy to the autarky case. It is given by

$$
\frac{\bar{w}}{w\left(\phi^{*}\right)}=\Gamma^{-1} \frac{k-\xi+\theta}{k-\xi} .
$$

Comparing $\bar{w} / w\left(\phi^{*}\right)$ with its autarky level in (24), we see that wage inequality rises if

\footnotetext{
${ }^{21}$ In the original Melitz model, both effects are captured by the effect of globalisation on the price index: The fall in the CES price index due to the increase in the mass of competitors leads to a decrease in demand at the firm level, see Melitz (2003, eq. (2)). This can be interpreted as a competition effect, as in our model, or as an increase in the real wage paid by all firms, which in his model equals $1 / P$ due to the normalisation of the nominal wage to one.
} 
an economy moves from autarky to trade in the presence of positive variable transport costs (so that $\Gamma<1$ ). Intuitively, the increase in cutoff productivity increases both per capita output and the wage paid by the marginal firm proportionally. As unemployment increases, the average wage of those employed increases more than proportionally, and $\bar{w} / w\left(\phi^{*}\right)$ rises. The wage effects of trade liberalisation are summarised in proposition 3.

Proposition 3. With positive variable transport costs and beachhead costs that are the same across all markets, opening up to trade raises the average wage and widens the wage differential $\bar{w} / w\left(\phi^{*}\right)$ in all participating countries.

This proposition gives new insights into the distributional consequences of trade liberalisation. While existing theoretical studies on that issue investigate the effects on wages of one skill group relative to another one, our model emphasises the wage dispersion effects within education/skill groups (as all workers have the same individual characteristics). The model points to the role of trade liberalisation as a candidate for explaining the observed increase of within-group wage inequality if productivity differences of firms paired with fairness preferences give rise to firm-specific payments to labour. This effect is triggered by a change in the composition and relative size of firms that differ in their productivity levels. ${ }^{22}$ To the best of our knowledge, there exists no conclusive empirical evidence on the role of trade liberalisation for within-group wage inequality. However, Bernard and Jensen (1995) find that exporters pay higher wages (for both production and non-production workers), even if controlling for plant size, capital intensity, hours per worker, industry and location. This gives (at least indirect) support for the economic mechanisms in this paper. ${ }^{23}$

\footnotetext{
${ }^{22}$ While the change in composition of domestic firms raises $w(\tilde{\phi})$ and $w\left(\phi^{*}\right)$ pari passu, without affecting the ratio of these two wage rates, the separation of firms according to their export status and the associated impact on the size of exporters relative to non-exporters induces an increase in the ratio of $\bar{w}$ to $w(\tilde{\phi})$. It is this second compositional effect due to selection of the most productive firms into export status which is responsible for the wage inequality effect of trade liberalisation in our analysis.

${ }^{23} \mathrm{It}$ is straightforward to show that quantitatively the effect of trade liberalisation on the key model variables described in propositions 2 and 3 depends on fairness preferences: The higher is $\theta$, the smaller is the positive effect of trade liberalisation on welfare and the average profit, and the larger are - subject
} 


\subsection{Marginal Trade Liberalisation}

Comparing the two scenarios of autarky and (restricted) trade, as we have done in the previous section, is analytically convenient but clearly does not adequately reflect the globalisation experience of the past decades, which has arguably been a gradual process. In the last twenty years more and more countries have opened their borders for international goods transactions and transport costs have fallen dramatically since World War II, leading some observers to proclaim the "death of distance" (Cairncross, 1997) to be imminent.

To gain insights into the development of unemployment and wage inequality during the process of globalisation, we analyze the comparative static effects of changes in transport $\operatorname{costs} \tau$ and the number of trading partners $n$. As in the last section, we look at the fully symmetric case where $f_{x}=f$. This implies $\chi=\tau^{-k /(1-\theta)}$ with $\partial \chi / \partial \tau<0$, and hence the proportion of firms that export increases with falling variable trading costs, as can be expected. Using this result, we find that a decrease in $\tau$ increases average productivity $\tilde{\phi}_{t}$ (from (33)) and therefore per capita output (from (18)). The same equations can be used to see that average productivity and per capita output increase in the number of partner countries $n$. This result is not surprising, as trade liberalisation per se has a positive effect on welfare. This effect is reinforced if more countries become economically integrated.

The effect of trade liberalisation in the form of either lowering $\tau$ or increasing $n$ on unemployment and the wage differential are determined by their respective effects on $\Gamma$, as can be seen from (37) and (38). Partially differentiating (36), we find $\partial \Gamma / \partial n<0$, and therefore an increase in the number of trading partners raises unemployment as well as the wage differential $\bar{w} / w\left(\phi^{*}\right)$. On the other hand, the effect of changes in variable transport costs on $\Gamma$ is non-monotonic. This follows from the result established earlier that the employment level in an integrated world with zero variable transport costs $(\tau=1)$ is equal to the autarky situation (which follows if $\tau \rightarrow \infty$ ), while employment falls if one

to only mild conditions - the negative effects on employment and wage inequality. The results on welfare and the average profit follow from (16), (31) and (33), noting that $\partial \chi / \partial \theta<0$. It has been shown above that both the employment and wage inequality effects of trade liberalisation are solely determined by $\Gamma$. We find that $k>1$ is sufficient for $d \Gamma / d \theta<0$, and hence the stated result follows. (Derivation details are available from the authors upon request.) 
moves from autarky to trade with positive variable transport costs $(\tau>1)$. Differentiating (36) with respect to $\tau$, we have

$$
\operatorname{sign}\left(\frac{\partial \Gamma}{\partial \tau}\right)=\operatorname{sign}\left(\frac{k\left[\tau^{\theta /(1-\theta)}-1\right]}{1+n \chi}-\theta\right),
$$

which allows us to identify a critical $\bar{\tau}>1$, such that $\partial \Gamma / \partial \tau>0$ if $\tau>\bar{\tau}$ and $\partial \Gamma / \partial \tau<0$ if $\tau<\bar{\tau}$. A marginal reduction in variable transport costs increases (decreases) unemployment and wage inequality if $\tau$ is larger (smaller) than $\bar{\tau}$.

The results derived so far allow us to address an issue that has featured prominently in both the political debate and the popular press in recent years: the simultaneous occurrence of increasing profits and increasing unemployment in the face of globalisation. Is there a reason to believe that these two phenomena are related? Our framework suggests that the decline in transport costs could be a common cause for both phenomena, and indeed might in addition have contributed to the increase in wage inequality. Notably however, the phenomenon that employment and firm profits move in opposite directions in our model disappears for low levels of transport costs. While further globalisation hence would have the potential for further increasing the profits of active firms, it should eventually, as the "death of distance" becomes a reality, lead to an increase in employment as well.

\section{Extensions}

The analysis in section 3 has built upon two important assumptions, namely (i) identical beachhead costs for domestic and foreign markets and (ii) no external economies of scale, due to our normalisation of the CES-aggregator in (1). We now check the robustness of our results by modifying these two model elements. In subsection 4.1, we allow for heterogeneous beachhead costs but keep the normalisation of the CES-aggregator. The role of external economies of scale is analysed in subsection 4.2. 


\subsection{Heterogeneous Beachhead Costs}

In this subsection, we look at the case where beachhead costs for domestic and export markets are different. There is no presumption as to which of these costs one should expect to be higher (which is what makes the benchmark case of $f_{x}=f$ interesting to begin with), and hence we will consider both $f_{x}>f$ and $f_{x}<f$. The analysis in this section is confined to deriving the effects of a movement from autarky to trade, i.e. an adaptation of the analysis in section 3.1 for the case of asymmetric beachhead costs. The analogue to the zero cutoff profit condition (31) is given by

$$
\bar{\pi}_{t}=\frac{\xi f}{k-\xi}\left(1+n \chi \frac{f_{x}}{f}\right)
$$

with $\chi=1$ if $\tau^{\sigma-1} f_{x} \leq f$. The productivity differential $\tilde{\phi}_{t} / \tilde{\phi}_{a}$ determining the welfare effect of globalisation can be written as

$$
\frac{\tilde{\phi}_{t}}{\tilde{\phi}_{a}}=\left\{\begin{array}{lll}
\left(\frac{1+n \tau^{1-\sigma}}{1+n}\right)^{1 / \xi}\left(1+n \frac{f_{x}}{f}\right)^{1 / k} & \text { if } & \tau^{\sigma-1} f_{x} \leq f \\
\left(\frac{1+n \chi \frac{f_{x}}{f}}{1+n \chi}\right)^{1 / \xi}\left(1+n \chi \frac{f_{x}}{f}\right)^{1 / k} & \text { if } & \tau^{\sigma-1} f_{x}>f
\end{array}\right.
$$

with the first term at the right-hand side of $\left(33^{\prime}\right)$ being equal to $\tilde{\phi}_{t} / \tilde{\phi}$ and the second term equalling $\phi^{*} / \phi_{a}^{*}$ (or, equivalently, $\tilde{\phi} / \tilde{\phi}_{a}$ ). The effect of globalisation on aggregate employment is still determined solely by the sign of $\Gamma-1$ (see (35) and (38)), where $\Gamma$ is now given by

$$
\Gamma=\left\{\begin{array}{ccc}
\left(\frac{1+n \tau^{1-\sigma}}{1+n}\right)^{\frac{\theta}{\xi}} & \text { if } & \tau^{\sigma-1} f_{x} \leq f \\
\left(\frac{1+n \chi \frac{f_{x}}{f}}{1+n \chi}\right)^{\frac{\theta}{\xi}} \frac{1+n \tau^{1-\sigma} \chi^{\frac{k-\xi+\theta}{k}}}{1+n \tau^{1-\sigma} \chi^{\frac{k-\xi}{k}}} & \text { if } & \tau^{\sigma-1} f_{x}>f
\end{array} .\right.
$$

The first term on the right hand side in both lines of $\left(36^{\prime}\right)$ equals $\left(\tilde{\phi}_{t} / \tilde{\phi}\right)^{\theta}$, and the second term in line two is smaller than or equal to one (as $\chi \leq 1)$.

For simplicity, we start by looking at the effects of globalisation for the borderline case of zero fixed and variable transport $\operatorname{costs}\left(f_{x}=0, \tau=1\right)$. As mentioned before and confirmed by inspection of $\left(33^{\prime}\right)$ and $\left(36^{\prime}\right)$, goods market integration in this case leaves welfare and employment unaffected. Now, increasing $\tau$ leaves relative cutoff productivities 
$\phi^{*} / \phi_{a}^{*}$ unchanged, but decreases $\tilde{\phi}_{t} / \tilde{\phi}$ due to the lost-in-transit effect. Overall, welfare and aggregate employment decrease. On the other hand, with $f_{x}>0$ we have $\phi^{*} / \phi_{a}^{*}>1$ and in addition $\tilde{\phi}_{t} / \tilde{\phi}>1$ due to the export-selection effect once the partitioning threshold is reached. Overall, welfare increases. Employment remains unchanged below the partitioning threshold, as it only depends on $\tilde{\phi}_{t} / \tilde{\phi}$, but not on $\phi^{*} / \phi_{a}^{*}$. In the partitioning regime, the employment effect may be positive or negative, depending on the particular parameter constellation.

With both fixed and variable transport costs strictly positive, the effects just described interact, and the overall welfare and employment effects depend ceteris paribus on the relative size of these costs. Rather than going through an unwieldy catalogue of cases, we focus on some insights that can be gained directly from inspecting $\left(33^{\prime}\right)$ and $\left(36^{\prime}\right)$. Firstly, higher variable transport costs reduce welfare and employment if there is no partitioning of firms. Hence, there is a tendency of globalisation to exhibit detrimental welfare and employment effects if variable transport costs are high and foreign beachhead costs are moderate. Secondly, $f_{x}>f$ is sufficient for positive welfare effects and necessary for positive employment effects of globalisation. ${ }^{24}$ Thus, there is a tendency for trade liberalisation to be beneficial if foreign beachhead costs are sufficiently high and there is partitioning of firms by their export status.

\subsection{External Economies of Scale}

This subsection addresses the impact of external economies of scale on the trade liberalisation effects identified in section 3. For this purpose, we replace technology (1) by the generalised CES-index ${ }^{25}$

$$
Y=M^{-\frac{\eta(1-\rho)}{\rho}}\left[\int_{v \in V} q(v)^{\rho} d v\right]^{1 / \rho}, \quad 0<\rho<1, \quad \eta \in[0,1] .
$$

\footnotetext{
${ }^{24}$ It is difficult to show positive employment effects of globalisation analytically. However, numerical simulation exercises indicate that such positive employment effects are possible if there is partitioning of firms by their export status.

${ }^{25}$ See Montagna (2001) for a similar exercise in a heterogeneous firms model without labour market imperfections.
} 
This production technology covers our specification without external scale effects $(\eta=1)$ and the standard specification of the CES technology as used by Ethier $(1982)(\eta=0)$ as two special cases. The existence of external scale effects (for $\eta<1$ ) drives a wedge between the price index $P$, which is normalised to one, and the price of the firm with average productivity, which is given by $p(\tilde{\phi})=M^{\frac{1-\eta}{\sigma-1}}$. By virtue of $\left(5^{\prime}\right)$, this has consequences for per capita output, and hence welfare:

$$
Y / L=\tilde{\phi} \rho^{\theta /(1-\theta)} M^{(1-\eta) / \xi},
$$

which depends positively on the mass of available input varieties $M$ if $\eta<1$. Hence, to the extent that the mass of available input varieties increases with country size (measured by aggregate labour supply), larger countries have higher welfare. In order to ensure stability of the autarky equilibrium we assume $\xi>1-\eta .^{26}$

Using $\left(18^{\prime}\right)$, the equilibrium mass of available intermediate goods can be determined in analogy to (19) and is given by:

$$
M=\left[\frac{\tilde{\phi} \rho^{\theta /(1-\theta)} L}{\sigma(\pi(\tilde{\phi})+f)}\right]^{\frac{\xi}{\xi-(1-\eta)}}
$$

In contrast to our benchmark model, a higher labour endowment $L$ now leads to a more than proportional increase in the mass of available input varieties.

With respect to the unemployment rate, we obtain

$$
1-U=\rho^{\theta /(1-\theta)}\left(\frac{k}{k-\xi}\right)^{\theta / \xi} \frac{k-\xi}{k-\xi+\theta} M^{\frac{\theta(1-\eta)}{\xi}},
$$

which simplifies to (21) if $\eta=1$. In contrast, with $\eta<1$ the unemployment rate exhibits a size pattern: The higher the labour endowment $L$, the greater an economy's mass of available input varieties and the lower is its unemployment rate (under autarky). For an interior solution with $U<1$, the endowment of labour must be sufficiently low. This is assumed in the following.

\footnotetext{
${ }^{26}$ In the opposite case of $\xi<1-\eta$, a marginal increase of $M$ (above $M_{a}$ ) would raise per capita output more than proportionally, thereby leading to further entry (due to $M=Y / r(\tilde{\phi})$ ) and ultimately driving both welfare and the mass of intermediate competitors up to infinity.
} 
The final variable of interest is within-group wage inequality $\bar{w} / w\left(\phi^{*}\right)$. Noting that $w(\tilde{\phi}) / w\left(\phi^{*}\right)$ is a constant if productivity levels are Pareto-distributed, we can investigate the role of market size by looking at $w(\tilde{\phi}) / \bar{w}$. By virtue of fair wage condition (5), we have $w(\tilde{\phi}) / \bar{w}=(1-U)[w(\tilde{\phi}) / \tilde{\phi}]^{-\theta /(1-\theta)}$ which, using $w(\tilde{\phi}) / \tilde{\phi}=\rho p(\tilde{\phi})=\rho M^{\frac{1-\eta}{\sigma-1}}$ together with $\left(21^{\prime}\right)$, turns out to be identical to (23). As a consequence, within-group wage inequality in (24) remains unaffected by the generalisation considered in this subsection.

We can now compare the autarky to the trade equilibrium, focussing, as in section 3 , on the symmetric case of identical beachhead costs in all markets: $f=f_{x}$. There are two channels through which trade liberalisation affects welfare. First, there are productivity gains, as the least productive firms leave the market: $\tilde{\phi}_{t}>\tilde{\phi}_{a}$ (see section 3). Second, the number of available input varieties goes up after trade liberalisation ${ }^{27}\left(M_{t}>M_{a}\right)$, which with $\eta<1$ increases welfare further. Concerning wage inequality, we know from the autarky scenario that the generalisation of production technology (1) has no implication for the relative wage $\bar{w} / w\left(\phi^{*}\right)$. Hence, the finding that a movement from autarky to trade amplifies wage inequality survives for all possible $\eta$-values.

Finally, following the analysis in section 3 , the employment rate in the trade scenario can be reformulated in the following way:

$$
1-U=\left(1-U_{a}\right) \Gamma\left(M_{t} / M_{a}\right)^{\theta(1-\eta) / \xi}
$$

There are two counteracting effects of trade liberalisation on the unemployment rate $U$. On the one hand, unemployment increases due to partitioning of firms by their export status (see section 3). On the other hand, there are additional positive labour demand effects if $\eta<1$ leads to external scale effects. Which of the two effects dominates critically depends on the size of transport costs $\tau$ and parameter $\eta$. In the borderline case of zero variable transport $\operatorname{costs} \tau=1$, we have $\Gamma=1$ and the partitioning effect vanishes. Thus, employment unambiguously increases after trade liberalisation through the second channel of influence. In contrast, if $\tau>1$ and the external scale effect is sufficiently weak, i.e. if

\footnotetext{
${ }^{27}$ Substitute $\tilde{\phi}_{t}$ for $\tilde{\phi}$ and $M_{t}$ for $M$ in $\left(19^{\prime}\right)$ and consider $\xi>1-\eta$. Then, $M_{t}>M_{a}$ follows immediately from $\tilde{\phi}_{t}>\tilde{\phi}_{a}$.
} 
$\eta$ is not too low, it is the first effect that dominates and the unemployment rate is higher under trade than under autarky. ${ }^{28}$

Summing up, we find that the results in section 3 for the impact of trade liberalisation on welfare and wage inequality are robust with respect to different degrees of external scale effects. However, our conclusions from the previous analysis on the unemployment effects of trade liberalisation have to be modified. A negative employment effect is triggered if variable transport costs are not too low and the external scale effects are moderate, while a positive employment effect can be expected if variable transport costs are negligible and the external scale effect is particularly strong. ${ }^{29}$

\section{Concluding remarks}

The role of globalisation for labour market performance has featured prominently in the economics debate for a long time. While the effect of trade liberalisation on the skill premium has been at the forefront of this debate, its effect on wage inequality between workers of the same skill group has been ignored. To address this issue, we develop a model that incorporates a fair wage mechanism into a general equilibrium framework with heterogeneous firms that differ in their productivity levels. Furthermore, we assume that rent-sharing motives are a determinant of workers' fair wage preferences, so that wage payments contain a firm-specific component. This gives a theoretical framework in which within-group wage inequality and unemployment are determined simultaneously, with the productivity distribution of active firms being a key factor of the labour market outcome. We then use this model to study the effects of international integration of goods markets

\footnotetext{
${ }^{28}$ It is noteworthy that $U>U_{a}$ is possible even if $\eta=0$.

${ }^{29}$ It is interesting to compare this result with the respective findings by Matusz (1996), who analyses the labour market effects of trade liberalisation in an Ethier (1982)-type framework with a Shapiro and Stiglitz (1984) model of efficiency wages. In this setting, trade liberalisation increases productivity and leads to higher real wages and higher employment. Matusz (1996) conducts his analysis in a setting without variable transport costs. In this case, our extended model with scale effects would also result in a higher employment level after trade liberalisation. However, if we allow for existence of variable transport costs, positive employment effects are no longer guaranteed in our framework.
} 
on national labour markets.

Noting from previous theoretical work that economic integration affects the productivity distribution of active producers, we have been particularly interested in how these changes translate into per capita output, unemployment and within-group wage inequality effects. In our fully symmetric benchmark model where domestic and foreign beachhead (market entry) costs are the same, there are gains from trade accompanied by higher average profits, higher unemployment and a larger wage dispersion. This highlights two distributional conflicts national governments face in the process of globalisation: One is due to the simultaneous occurrence of higher average profits and higher unemployment. The second distributional conflict arises between workers employed by different firms: Those who stay employed benefit to different extents from the gains from trade, while those who become newly unemployed lose.

In one extension to our basic setting we allow for differences in the costs of domestic and foreign market entry. In this more general setting, two important results have been identified: If foreign beachhead costs are sufficiently high, in addition to there being gains from trade economic integration may reduce both within-group wage inequality and the unemployment rate. However, if foreign beachhead costs are low, trade liberalisation may reduce per capita output and welfare. In this case, both within-group wage inequality and the unemployment rate definitely increase.

In future work our framework can be extended in a number of directions. For one, it would be potentially fruitful to introduce trade policy instruments into the model and to look at their effect on welfare and the labour market. Another promising area for future research is the addition of a second factor of production that would allow the simultaneous discussion of within-group and between-group wage inequality. 


\section{Appendix}

\section{Proof of Proposition 1}

First, $d \bar{\pi} / d \theta<0$ is a direct consequence of (16). Second, it follows from (18), that

$$
\frac{d(Y / L)}{d \theta}=\frac{Y}{L}\left[\frac{1}{(1-\theta)^{2}} \ln \rho+\frac{1}{\tilde{\phi}} \frac{d \tilde{\phi}}{d \theta}\right]
$$

which given that $\rho \in(0,1)$ is negative if $d \tilde{\phi} / d \theta<0$. Substituting (17) into (14) and differentiating the respective expression with respect to $\theta$ we obtain

$$
\frac{d \tilde{\phi}}{d \theta}=\left[\frac{\tilde{\phi}}{\xi} \Omega(k, \xi)+\frac{\tilde{\phi}}{\phi^{*}} \frac{d \phi^{*}}{d \xi}\right] \frac{d \xi}{d \theta},
$$

with

$$
\Omega(k, \xi) \equiv-\frac{1}{\xi} \ln \left(\frac{k}{k-\xi}\right)+\frac{1}{k-\xi}
$$

To determine the sign of $\Omega(\cdot)$ we use

$$
\frac{\partial \Omega(k, \xi)}{\partial k}=-\frac{\xi}{k(k-\xi)^{2}}<0 .
$$

Together with $\lim _{k \rightarrow \infty} \Omega(k, \xi)=0$, this implies that $\Omega(k, \xi)>0$ for any $k \in(\xi, \infty)$. Noting further that $d \phi^{*} / d \xi>0$ (from (17)) and $d \xi / d \theta=-(\sigma-1)<0$, we have $d \tilde{\phi} / d \theta<0$ and thus $d(Y / L) / d \theta<0$.

Third, differentiating (21) with respect to $\theta$ gives

$$
\begin{aligned}
\frac{d(1-U)}{d \theta}=(1-U)\left\{\frac{1}{(1-\theta)^{2}}\right. & {\left[\ln \rho+\frac{1}{\sigma-1} \ln \left(\frac{k}{k-(\sigma-1)(1-\theta)}\right)\right] } \\
- & \left.\frac{1}{k-(\sigma-1)(1-\theta)}\left[\frac{\theta}{1-\theta}+\frac{k-(\sigma-1)}{k+1-\sigma(1-\theta)}\right]\right\},
\end{aligned}
$$

which is negative if inequality (22) holds. Fourth, differentiating (24) with respect to $\theta$ gives

$$
\frac{d\left(\bar{w} / w\left(\phi^{*}\right)\right)}{d \theta}=\frac{k-(\sigma-1)}{(k-\xi)^{2}},
$$

which is positive, due to inequality (22). 


\section{References}

Aghion, P., Howitt, P., Violante, G.L. (2002), General Purpose Technology and Wage Inequality, Journal of Economic Growth 7, 315-345.

Agell, J., Lundborg, P., (1992), Fair Wages, Involuntary Unemployment and Tax Policies in the Simple General Equilibrium Model, Journal of Public Economics 47, 299-320.

Akerlof, G.A. (1982), Labor Contracts as Partial Gift Exchange, Quarterly Journal of Economics 97, 543-569.

Akerlof, G.A., Yellen, J.L. (1990), The Fair Wage-Effort Hypothesis and Unemployment, Quarterly Journal of Economics 105, 255-283.

Baldwin, R. (2005), Heterogeneous Firms and Trade: Testable and Untestable Properties of the Melitz Model, NBER Working Paper 11471.

Barth, E., Lucifora, C. (2006), Wage Dispersion, Markets and Institutions: The Effects of the Boom in Education on the Wage Structure, IZA Discussion Paper 2181.

Bayard,K., Troske, K.R. (1999), Examining the Employer-Size Wage Premium in the Manufacturing, Retail Trade, and Service Industries Using Employer-Employee Matched Data, American Economic Review 89, 99-103.

Bernard, A.B., Eaton, J., Jensen, J.B., Kortum, S. (2003), Plants and Productivity in International Trade, American Economic Review 93, 1268-1290.

Bernard, A.B., Jensen, J.B. (1995), Exporters, Jobs, and Wages in U.S. Manufacturing: 1976-1987, Brookings Papers on Economic Activity. Microeconomics n.V., 67-119.

Bernard, A.B., Jensen, J.B. (1999), Exceptional Exporter Performance: Cause, Effect, or Both?, Journal of International Economics 47, 1-25.

Bernard, A.B., Redding, S.J., Schott, P.K. (2007), Comparative Advantage and Heterogeneous Firms, Review of Economic Studies 74, 31-66. 
Bewley, T. (2005), Fairness, Reciprocity, and Wage Rigidity, in: Gintis, H., Bowles, S., Boyd, R., Fehr, E. (Eds.), Moral Sentiments and Material Interests: The Foundations of Cooperation in Economic Life. Cambridge/Mass., MIT Press, 303-338.

Blanchard, O., Giavazzi, F. (2003), Macroeconomic Effects of Regulation and Deregulation in Goods and Factor Markets, Quarterly Journal of Economics 118, 879-907.

Blanchflower, D.G., Oswald, A.J., Sanfey, P. (1996), Wages, Profits, and Wage Sharing, Quarterly Journal of Economics 111, 227-251.

Cairncross, F. (1997), The Death of Distance: How the Communication Revolution will Change our Lives. Cambridge/Mass.: Harvard Business School Press.

Clerides, S.K., Lach, S., Tybout, J.R. (1998), Is Learning by Exporting Important? Micro-Dynamic Evidence from Colombia, Mexico, and Morocco, Quarterly Journal of Economics 113, 903-947.

Danthine, J.P., Kurmann, A. (2006), Efficiency Wages Revisited: The Internal Reference Perspective, Economics Letters 90, 278-284.

Davidson, C., Matusz, S.J., Shevchenko, A. (2006), Globalization and Firm Level Adjustment with Imperfect Labor Markets, mimeo, Michigan State University.

Del Gatto, M., Mion, G., Ottaviano, G.I.P. (2006), Trade Integration, Firm Selection and the Costs of Non-Europe, CEPR Discussion Paper $\mathbf{5 7 3 0 .}$

Egger, H., Grossmann, V. (2005), Non-Routine Tasks, Restructuring of Firms, and Wage Inequality Within and Between Skill-Groups, Journal of Economics 86, 197-228.

Egger, H., Kreickemeier, U. (2007), International Fragmentation: Boon or Bane for Domestic Employment?, European Economic Review, forthcoming.

Ethier, W.J. (1982), National and International Returns to Scale in the Modern Theory of International Trade, American Economic Review 72, 389-405. 
Fehr, E., Falk, A. (1999), Wage Rigidity in a Competitive Incomplete Contract Market, Journal of Political Economy 107, 106-134.

Fehr, E., Gächter, S. (2000), Fairness and Retaliation: The Economics of Reciprocity, Journal of Economic Perspectives 14, 159-181.

Felbermayr, G., Prat, J. (2007), Product Market Regulation, Firm Selection and Unemployment, IZA Discussion Paper 2754.

Galor, O., Moav, O. (2000), Ability-Biased Technological Transition, Wage Inequality, and Economic Growth, Quarterly Journal of Economics 115, 469-497.

Grossman, G., Helpman, E. (2007), Fair Wages and Foreign Sourcing, unpublished manuscript, Harvard University.

Helpman, E., Melitz, M.J., Yeaple, S.R. (2004), Export Versus FDI with Heterogeneous Firms, American Economic Review 94, 300-316.

Hildreth, A.K.G., Oswald, A.J. (1997), Rent-Sharing and Wages: Evidence from Company and Establishment Panels, Journal of Labor Economics 15, 318-337.

Howitt, P. (2002), Looking Inside the Labor Market: A Review Article, Journal of Economic Literature 40, 125-138.

Juhn, C., Murphy, K.M., Pierce, B. (1993), Wage Inequality and the Rise in Returns to Skill, Journal of Political Economy 101, 410-442.

Katz, L.F., Autor, D.H. (1999), Changes in the Wage Structure and Earnings Inequality, in: Ashenfelter, O., Card, D. (eds.), Handbook of Labor Economics, Vol. 3A. Amsterdam, Elsevier, 1463-1555.

Kreickemeier, U., Nelson, D. (2006), Fair Wages, Unemployment and Technological Change in a Global Economy, Journal of International Economics 70, 451-469.

Matusz, S.J. (1994), International Trade Policy in a Model of Unemployment and Wage Differentials, Canadian Journal of Economics 27, 939-949. 
Matusz, S.J. (1996), International Trade, the Division of Labor, and Unemployment, International Economic Review 37, 71-84.

Melitz, M.J. (2003), The Impact of Trade on Intra-Industry Reallocations and Aggregate Industry Productivity, Econometrica 71, 1695-1725.

Montagna, C. (2001), Efficiency Gaps, Love of Variety and International Trade, Economica 68, 27-44.

Scheve, K., Slaughter, M. (2001), Globalization and the Perceptions of American Workers, Institute for International Economics, Washington, DC.

Shapiro, C., Stiglitz, J.E. (1984), Equilibrium Unemployment as a Worker Discipline Device, American Economic Review 74, 433-444.

Waelde, K., Weiss, P. (2007), International Competition, Downsizing and Wage Inequality, Journal of International Economics, forthcoming.

Winter-Ebmer, R., Zweimüller, J. (1999), Firm-Size Wage Differentials in Switzerland: Evidence from Job-Changers, American Economic Review 89, 89-93.

Yeaple, S.R. (2005), A Simple Model of Firm Heterogeneity, International Trade, and Wages, Journal of International Economics 65, 1-20. 


\section{CESifo Working Paper Series}

(for full list see www.cesifo-group.de)

1936 Naércio Aquino Menezes Filho and Marc-Andreas Muendler, Labor Reallocation in Response to Trade Reform, March 2007

1937 Gebhard Flaig and Timo Wollmershaeuser, Does the Euro-zone Diverge? A Stress Indicator for Analyzing Trends and Cycles in Real GDP and Inflation, March 2007

1938 Michael Funke and Michael Paetz, Environmental Policy Under Model Uncertainty: A Robust Optimal Control Approach, March 2007

1939 Byeongchan Seong, Sung K. Ahn and Peter A. Zadrozny, Cointegration Analysis with Mixed-Frequency Data, March 2007

1940 Monika Bütler and Michel André Maréchal, Framing Effects in Political Decision Making: Evidence from a Natural Voting Experiment, March 2007

1941 Giacomo Corneo and Olivier Jeanne, A Theory of Tolerance, March 2007

1942 Qing Hong and Michael Smart, In Praise of Tax Havens: International Tax Planning and Foreign Direct Investment, March 2007

1943 Yin-Wong Cheung, Dickson Tam and Matthew S. Yiu, Does the Chinese Interest Rate Follow the US Interest Rate?, March 2007

1944 Panu Poutvaara and Mikael Priks, Unemployment and Gang Crime: Could Prosperity Backfire?, March 2007

1945 Burkhard Heer, On the Modeling of the Income Distribution Business Cycle Dynamics, March 2007

1946 Christoph A. Schaltegger and Lars P. Feld, Are Fiscal Adjustments less Successful in Decentralized Governments?, March 2007

1947 Giovanni Facchini, Marcelo Olarreaga, Peri Silva and Gerald Willmann, Substitutability and Protectionism: Latin America's Trade Policy and Imports from China and India, March 2007

1948 C. Mirjam van Praag and Bernard M. S. van Praag, The Benefits of Being Economics Professor A (and not Z), March 2007

1949 Astrid Hopfensitz and Frans van Winden, Dynamic Choice, Independence and Emotions, March 2007

1950 Guglielmo Maria Caporale and Luis A. Gil-Alana, A Multivariate Long-Memory Model with Structural Breaks, March 2007 
1951 Mattias Ganslandt and Keith E. Maskus, Wholesale Price Discrimination and Parallel Imports, March 2007

1952 Michela Redoano, Fiscal Interactions Among European Countries. Does the EU Matter?, March 2007

1953 Stefan C. Wolter, Rémy Hübschi and Matthias Müller, Push or Pull? An Empirical Analysis of the Demand for Individual Project Grants from the Swiss National Science Foundation, March 2007

1954 Scott Alan Carson, African-American and White Inequality in the American South: Evidence from the $19^{\text {th }}$ Century Missouri State Prison, March 2007

1955 Peter Egger, Marko Koethenbuerger and Michael Smart, Do Fiscal Transfers Alleviate Business Tax Competition? Evidence from Germany, March 2007

1956 Panu Poutvaara and Lars-H. R. Siemers, Smoking and Social Interaction, March 2007

1957 Stephan Danninger and Fred Joutz, What Explains Germany's Rebounding Export Market Share?, March 2007

1958 Stefan Krasa and Mattias Polborn, Majority-efficiency and Competition-efficiency in a Binary Policy Model, March 2007

1959 Thiess Buettner and Georg Wamser, Intercompany Loans and Profit Shifting Evidence from Company-Level Data, March 2007

1960 Per Pettersson-Lidbom and Mikael Priks, Behavior under Social Pressure: Empty Italian Stadiums and Referee Bias, April 2007

1961 Balázs Égert and Carol S. Leonard, Dutch Disease Scare in Kazakhstan: Is it real?, April 2007

1962 Paul De Grauwe and Pablo Rovira Kaltwasser, Modeling Optimism and Pessimism in the Foreign Exchange Market, April 2007

1963 Volker Grossmann and Thomas M. Steger, Anti-Competitive Conduct, In-House R\&D, and Growth, April 2007

1964 Steven Brakman and Charles van Marrewijk, It's a Big World After All, April 2007

1965 Mauro Ghinamo, Paolo M. Panteghini and Federico Revelli, FDI Determination and Corporate Tax Competition in a Volatile World, April 2007

1966 Inés Macho-Stadler and David Pérez-Castrillo, Optimal Monitoring to Implement Clean Technologies when Pollution is Random, April 2007

1967 Thomas Eichner and Ruediger Pethig, Efficient $\mathrm{CO}_{2}$ Emissions Control with National Emissions Taxes and International Emissions Trading, April 2007 
1968 Michela Redoano, Does Centralization Affect the Number and Size of Lobbies?, April 2007

1969 Christian Gollier, Intergenerational Risk-Sharing and Risk-Taking of a Pension Fund, April 2007

1970 Swapan K. Bhattacharya and Biswa N. Bhattacharyay, Gains and Losses of India-China Trade Cooperation - a Gravity Model Impact Analysis, April 2007

1971 Gerhard Illing, Financial Stability and Monetary Policy - A Framework, April 2007

1972 Rainald Borck and Matthias Wrede, Commuting Subsidies with two Transport Modes, April 2007

1973 Frederick van der Ploeg, Prudent Budgetary Policy: Political Economy of Precautionary Taxation, April 2007

1974 Ben J. Heijdra and Ward E. Romp, Retirement, Pensions, and Ageing, April 2007

1975 Scott Alan Carson, Health during Industrialization: Evidence from the $19^{\text {th }}$ Century Pennsylvania State Prison System, April 2007

1976 Andreas Haufler and Ian Wooton, Competition for Firms in an Oligopolistic Industry: Do Firms or Countries Have to Pay?, April 2007

1977 Eckhard Janeba, Exports, Unemployment and the Welfare State, April 2007

1978 Gernot Doppelhofer and Melvyn Weeks, Jointness of Growth Determinants, April 2007

1979 Edith Sand and Assaf Razin, The Role of Immigration in Sustaining the Social Security System: A Political Economy Approach, April 2007

1980 Marco Pagano and Giovanni Immordino, Optimal Regulation of Auditing, May 2007

1981 Ludger Woessmann, Fundamental Determinants of School Efficiency and Equity: German States as a Microcosm for OECD Countries, May 2007

1982 Bas Jacobs, Real Options and Human Capital Investment, May 2007

1983 Steinar Holden and Fredrik Wulfsberg, Are Real Wages Rigid Downwards?, May 2007

1984 Cheng Hsiao, M. Hashem Pesaran and Andreas Pick, Diagnostic Tests of Cross Section Independence for Nonlinear Panel Data Models, May 2007

1985 Luis Otávio Façanha and Marcelo Resende, Hierarchical Structure in Brazilian Industrial Firms: An Econometric Study, May 2007

1986 Ondřej Schneider, The EU Budget Dispute - A Blessing in Disguise?, May2007 
1987 Sascha O. Becker and Ludger Woessmann, Was Weber Wrong? A Human Capital Theory of Protestant Economic History, May 2007

1988 Erkki Koskela and Rune Stenbacka, Equilibrium Unemployment with Outsourcing and Wage Solidarity under Labour Market Imperfections, May 2007

1989 Guglielmo Maria Caporale, Juncal Cunado and Luis A. Gil-Alana, Deterministic versus Stochastic Seasonal Fractional Integration and Structural Breaks, May 2007

1990 Cláudia Costa Storti and Paul De Grauwe, Globalization and the Price Decline of Illicit Drugs, May 2007

1991 Thomas Eichner and Ruediger Pethig, Pricing the Ecosystem and Taxing Ecosystem Services: A General Equilibrium Approach, May 2007

1992 Wladimir Raymond, Pierre Mohnen, Franz Palm and Sybrand Schim van der Loeff, The Behavior of the Maximum Likelihood Estimator of Dynamic Panel Data Sample Selection Models, May 2007

1993 Fahad Khalil, Jacques Lawarrée and Sungho Yun, Bribery vs. Extortion: Allowing the Lesser of two Evils, May 2007

1994 Thorvaldur Gylfason, The International Economics of Natural Resources and Growth, May 2007

1995 Catherine Roux and Thomas von Ungern-Sternberg, Leniency Programs in a Multimarket Setting: Amnesty Plus and Penalty Plus, May 2007

1996 J. Atsu Amegashie, Bazoumana Ouattara and Eric Strobl, Moral Hazard and the Composition of Transfers: Theory with an Application to Foreign Aid, May 2007

1997 Wolfgang Buchholz and Wolfgang Peters, Equal Sacrifice and Fair Burden Sharing in a Public Goods Economy, May 2007

1998 Robert S. Chirinko and Debdulal Mallick, The Fisher/Cobb-Douglas Paradox, Factor Shares, and Cointegration, May 2007

1999 Petra M. Geraats, Political Pressures and Monetary Mystique, May 2007

2000 Hartmut Egger and Udo Kreickemeier, Firm Heterogeneity and the Labour Market Effects of Trade Liberalisation, May 2007 